\title{
An Electrostatic Field on a Bioceramic Growth Surface Suppressed Leiomyosarcoma Cell Proliferation but Accelerated Differentiation Tatsuya Hattori' ${ }^{1,2}$, Kaori Igarashi ${ }^{1}$, Haruka Miyazaki ${ }^{1,3}$, Mamoru Aizawa ${ }^{2}$, Keiichi Katayama ${ }^{3}$, Kimihiro Yamashita ${ }^{1}$ and Akiko Nagai ${ }^{1, *}$
}

${ }^{1}$ Institute of Biomaterials and Bioengineering, Tokyo Medical and Dental University, 2-3-10 Kanda-Surugadai, Chiyoda, Tokyo 101-0062, Japan ${ }^{2}$ Department of Applied Chemistry, School of Science and Technology, Meiji University, 1-1-1Higashimita, Tama, Kawasaki 214-8571, Japan ${ }^{3}$ Department of Applied Chemistry, Tokai University, 4-1-1 Kitakaname, Hiratsuka 259-1292, Japan

\begin{abstract}
Living bodies make use of endogenous electric energies for biological processes and can be affected by exogenous energies as well. Certain exogenous energies, such as the electric field of a polarized bioceramic surface, have been reported to have potency as part of an adjunct therapy for malignant tumors. Here, we investigated the effects of an electrostatic field on a leiomyosarcoma cell line cultured on polarized hydroxyapatite. We found that growth on the polarized surface suppressed cell proliferation, but the occurrence of apoptosis was low. In addition, our examination of cell cyclerelated genes revealed that the expression levels of two markers of myogenic differentiation were increased and tumor suppressor genes were up-regulated. These results indicated that inhibition of DNA replication led to the suppression of proliferation and acceleration of differentiation. Further studies on the electric fields produced around polarized bioceramic surfaces and their effects on cell cycle regulation might enable the design of an effective differentiation-inducing therapy for leiomyosarcoma and other cancers.
\end{abstract}

\section{Introduction}

The electric signals associated with cells facilitate various biological processes in living bodies. Nerve cells are able to concentrate ions and generate a membrane potential, with a high difference of charge between the inside and outside of the cell, and rapid de-polarization enables a rapid transmission of information along a nerve fiber [1]. It has been reported that electrical energy emanating from sources outside the body can also affect cellular responses, such as cell migration and proliferation [2,3]. It has been observed that there is an electrical gradient between tumor and normal tissues and that malignant and normal cells have differential sensitivities for electric energy [4]. Based upon these results, a new line of research is developing that aims to use electric fields or currents in the localized treatment of malignant tumors [5-7].

We have shown that electric polarization treatment on bioceramics, such as hydroxyapatite and titania, produced electric fields around the material and induced surface charges without even microscopic changes of the surface morphology or alterations of the chemical composition $[8,9]$. Because these polarized ceramic biomaterials can be charged with electric energy before implantation inside the body, large-scale equipment is not needed at the point of use. The electrostatic energy stored in the polarized apatite and/or titania has been reported to control protein adsorption, to modify initial osteoblast responses, and to promote bone healing, including osteoblast proliferation and differentiation into osteocytes [10-13]. Also seen in animal models, polarization inhibited neointimal hyperplasia after angioplasty, by reducing the proliferation of endothelial cells and influencing the differentiation of smooth muscle cells [14]. These results indicate that the electric signals produced by surface fields around bioceramics can affect the balance of cell proliferation and differentiation. The coordination of these two cellular processes is especially important for the growth and maintenance of stem cells that are able to divide while maintaining their pluripotency [15]. To control the balance in malignant tumors could lead to suppress their uncontrolled expansion.

\section{Publication History:}

Received: August 26, 2016

Accepted: November 01, 2016

Published: November 03, 2016

\section{Keywords:}

Electrostatic field, Cell cycle, leiomyosarcoma cells, Bioceramics, Electric polarization, Differentiation-inducing therapy

The current treatment for leiomyosarcoma is usually a combination of tumorectomy, chemotherapy, and radiotherapy. Despite improvements in these treatments, the prognosis of this solid tumor disease is still poor due to high rates of local recurrence and distant metastasis. An adjunct therapy that has an orthogonal anti-tumor action and can be used in conjunction with those therapies must be developed to improve the outcome for this disease. Recently, the new approach of differentiation-inducing therapy, in which tumor cells are influenced to differentiate into mature cells has been applied in a clinical setting. Specifically, all-trans retinoic acid was used to treat acute promyelocytic leukemia [16-18]. The malignancy of leiomyosarcoma may be reduced by using extrinsic influences, such as electric fields to switch the smooth muscle cells to a differentiated phenotype with a slower growth rate [19].

The molecular basis of the switch between replication as a stem cell and adoption of a particular cellular fate has been recently analyzed using cell cycle research in a cross-disciplinary manner [20,21]. In the present study, we examined the effects of the electric energy of a polarized apatite growth surface on the regulation of proliferation and differentiation of tumor cells, using the human uterine leiomyosarcoma cell line SK-LMS-1 (SK). This cell line has become immortalized, making it similar to stem or tumor cells, but can still be differentiated by some external signals, and its status can be evaluated by markers of differentiation, such as calponin and caldesmon [22,23]. Furthermore, the molecular mechanism of cell fate regulation, as affected by growth on a polarized surface, was investigated by examining changes in the expression of cell cycle-related genes.

"Corresponding Author: Prof. Akiko Nagai, Institute of Biomaterials and Bioengineering, Tokyo Medical and Dental University, 2-3-10 Kanda-Surugadai, Chiyoda, Tokyo 101-0062, Japan; E-mail: nag-bcr@tmd.ac.jp

Citation: Hattori T, Igarashi K, Miyazaki H, Aizawa M, Katayama K, et al. (2016) An Electrostatic Field on a Bioceramic Growth Surface Suppressed Leiomyosarcoma Cell Proliferation but Accelerated Differentiation. Int J Metall Mater Eng 2: 127. doi: https://doi.org/10.15344/2455-2372/2016/127

Copyright: (c) 2016 Hattori et al. This is an open-access article distributed under the terms of the Creative Commons Attribution License, which permits unrestricted use, distribution, and reproduction in any medium, provided the original author and source are credited. 
Citation: Hattori T, Igarashi K, Miyazaki H, Aizawa M, Katayama K, et al. (2016) An Electrostatic Field on a Bioceramic Growth Surface Suppressed Leiomyosarcoma Cell Proliferation but Accelerated Differentiation. Int J Metall Mater Eng 2: 127. doi: https://doi.org/10.15344/2455-2372/2016/127

Page 2 of 6

\begin{abstract}
Materials and Method
Preparation of specimens

Hydroxylapatite (HAp) powders synthesized by a wet method were uniaxially pressed into pellets. Then they were sintered at $1250^{\circ} \mathrm{C}$ for $2 \mathrm{~h}$ under a water vapor stream [24]. The specimen, a disk $10 \mathrm{~mm}$ in diameter and $0.8 \mathrm{~mm}$ thick, was sandwiched between a pair of platinum $(\mathrm{Pt})$ plate electrodes, electrically polarized in a DC field of $5 \mathrm{kV} \cdot \mathrm{cm}-1$ in an air atmosphere at $400^{\circ} \mathrm{C}$ for $1 \mathrm{~h}$, and then cooled to room temperature under the applied DC voltage [24,25]. The surface of specimens in contact with the cathode was labeled the negative surface (N-surface), and the surface placed in contact with the anode was labeled the positive surface (P-surface). A non-polarized specimen was heated in air at $400^{\circ} \mathrm{C}$ for $1 \mathrm{~h}$ with no electric field and labeled the 0 -surface.
\end{abstract}

\section{Characterization of the specimens}

The crystal phase of the specimen was determined with a powder $\mathrm{X}$-ray diffractometer (XRD, Bruker AXS D8 Advance) using Cu K radiation. Fourier transform infrared spectroscopy (FT-IR) was used to analyze the HAp specimens using the $\mathrm{KBr}$ pellet method (JASCO FT/IR-500 spectrometer). The thermally stimulated depolarization current (TSDC) of the polarized samples was measured using a picoampere meter (Keithley Inc., OH, USA). Each polarized sample was sandwiched between Pt electrodes and heated to $670^{\circ} \mathrm{C}$ in an electric furnace equipped with a stainless-steel shielded sample chamber at a heating rate of $5^{\circ} \mathrm{C} \mathrm{min}^{-1}$. The stored charge was calculated by integration of the current density on the measurement as previously reported [26].

\section{Cell culture}

The human vulvar uterine leiomyosarcoma cell line, SK-LMS-1 (American Type Culture Collection) was grown in DMEM supplemented with $10 \%$ fetal bovine serum, $1 \%$ non-essential amino acids, and $1 \%$ Penicillin/Streptomycin.

\section{Cell proliferation assay and apoptosis assay}

Cell viability was quantitatively analyzed by using an MTT assay, which is widely used for measuring cytotoxity and proliferation. After seeding for 1,3 , or 6 days, the specimens were incubated with an MTT solution (5 mg/ml, Dojindo, Japan) at $37^{\circ} \mathrm{C}$ for $3 \mathrm{~h}$. The formazan product, which was obtained by the reduction of MTT in the mitochondria of viable cells, was dissolved in dimethyl sulfoxide for $10 \mathrm{~min}$ and the absorbance was measured at $570 \mathrm{~nm}$ using a microplate reader (Bio-Rad, CA, USA). The DeadEnd ${ }^{\mathrm{Tx}}$ Colorimetric Apoptosis Detection System (Promega, IL, USA) was used to visualize fragmented DNA arising from apoptotic cells. The terminal deoxynucleotidyl transferase deoxy-UTP nick end labeling (TUNEL)-positive cells in the resulting digital images (Olympus IX71 fluorescence microscope and DP71 digital camera; Olympus, Tokyo, Japan) were counted using MetaMorph software (Molecular Devices, CA, USA).

\section{Measurement of gene expression by quantitative real-time reverse transcription-polymerase chain reaction (qRT-PCR) analysis}

Total RNA from cells cultured for $24 \mathrm{~h}$ was extracted using spin columns according to the manufacturer's instructions (Quick-RNA
Micro Prep Kit, Zymo Research, Irvine, CA). Two micrograms of total RNA was used in transcription to create cDNA using SuperScript VILO according to the manufacturer's protocol (Invitrogen). Then, the synthesized cDNA was used directly in qRTPCR analyses with the LightCycler System (Roche Applied Science, IN, USA). Amplifications were performed using a hydrolysis probe and primers obtained from the Human Universal ProbeLibrary (Roche) for selective genes $(\mathrm{N}=$ 4, the primers and universal probes are listed in Table 1) or RealTime ready Human Cell Cycle Regulation Panel for the array analysis in combination with LightCycler 480 Probes Master (Roche). Results were quantified based on the threshold cycle $(\mathrm{Ct})$ value according to the $2^{-\Delta \Delta \mathrm{Ct}}$ method and normalized using the reference gene GAPDH. The fold changes in expression were compared between samples from polarized and non-polarized specimens. Increases of more than 1.75fold and decreases to less than 0.75 -fold were defined as substantial.

\section{Statistical analysis}

All the values are presented as the means \pm standard deviation. Statistical analyses were performed using one-way analysis of variance followed by a post-hoc test for multiple comparisons (Ryan's test) with $P<0.05$ considered statistically significant (ANOVA4 on the Web, Japan).

\section{Results}

\section{Characterization of the polarized HAp}

All specimens have more than $95 \%$ of the theoretical density value of HAp $\left(3.16 \mathrm{~g} / \mathrm{cm}^{3}\right)$. The results of XRD and FT-IR analyses indicated that all the specimens consisted of a single apatitic phase of crystalline HAp (JCPDS 09-0432) and the IR absorption spectra of the specimens showed the typical absorption bands corresponding to the modes of phosphate at $1074 \mathrm{~cm}^{-1} / 1044 \mathrm{~cm}^{-1}(\mathrm{v} 3), 962 \mathrm{~cm}^{-1}(\mathrm{v} 1)$, and $601 \mathrm{~cm}$ ${ }^{1} / 570 \mathrm{~cm}^{-1}(\mathrm{v} 4)$ and hydroxyl at $3569 \mathrm{~cm}^{-1}$ and $630 \mathrm{~cm}^{-1}$ (Figure 1a and Figure $1 \mathrm{~b}$ ). In addition, there were no obvious changes in morphology or phase composition after electric polarization. The average stored charges of the polarized specimens calculated from the TSDC curves were $2.8 \mu \mathrm{C} . \mathrm{cm}^{-2}$, and the charges of non-polarized specimens were too low to be measured (Figure 1c).

\section{Cell proliferation, apoptosis, and differentiation}

SK cells grown on culture glass, on polarized apatite, or on control non-polarized apatite, were evaluated by MTT assays 1,3 , or $6 \mathrm{~d}$ after seeding (Figure 2a and Figure 2b). The proliferation rates of the cells on all substrata increased with time. Although there were no significant differences among the three surfaces at $1 \mathrm{~d}$ and $3 \mathrm{~d}$, the proliferation rates of cells on the polarized specimens decreased at $6 \mathrm{~d}$ compared to the non-polarized surface.

To examine the reasons for the differences of the proliferation rates among the specimens, an apoptosis assay was performed that detected the number of TUNEL-positive cells (Figure 3a). There were a small number of apoptotic cells on the apatite specimens with or without polarization. Then the degree of differentiation was evaluated using real-time reverse transcriptase PCR. Calponin and caldesmon, markers specific to smooth muscle cells, can reflect the degree of differentiation of SK cells. The expression levels of these two genes were ranked highest to lowest for cells grown on the $\mathrm{P}$-surface, $\mathrm{N}$-surface, and 0 -surface (Figure $3 \mathrm{~b}$ and Figure $3 \mathrm{c}$ ). The results seemed to correlate with a ranking according to decreasing proliferation rates(greater decreases on the polarized surfaces than on the 0 -surface). 
Citation: Hattori T, Igarashi K, Miyazaki H, Aizawa M, Katayama K, et al. (2016) An Electrostatic Field on a Bioceramic Growth Surface Suppressed Leiomyosarcoma Cell Proliferation but Accelerated Differentiation. Int J Metall Mater Eng 2: 127. doi: https://doi.org/10.15344/2455-2372/2016/127

Page 3 of 6

\begin{tabular}{|c|c|c|c|}
\hline \multirow[t]{2}{*}{ glyceraldehyde 3-phosphate dehydrogenase GAPDH } & primer & $\begin{array}{l}\text { left } \\
\text { right }\end{array}$ & $\begin{array}{l}\text { CTCTGCTCCTCCTGTTCGAC } \\
\text { ACGACCAAATCCGTTGACTC }\end{array}$ \\
\hline & probe & $\# 60$ & \\
\hline \multirow[t]{2}{*}{ anaphase-promoting complex subunit 4 (ANAPC4) } & primer & $\begin{array}{l}\text { left } \\
\text { right }\end{array}$ & $\begin{array}{l}\text { TATCCGCCGCTACCTGAG } \\
\text { AACAGCCAGGTCCCCTGT }\end{array}$ \\
\hline & probe & $\# 5$ & \\
\hline \multirow[t]{2}{*}{ cyclin-dependent kinase 2 (CDK2) } & primer & $\begin{array}{l}\text { left } \\
\text { right }\end{array}$ & $\begin{array}{l}\text { ATGGATGCCTCTGCTCTCAC } \\
\text { CCGATGAGAATGGCAGAAAG }\end{array}$ \\
\hline & probe & $\# 81$ & \\
\hline \multirow[t]{2}{*}{ cyclin-dependent kinase inhibitor 2A (CDKN2A) } & primer & $\begin{array}{l}\text { left } \\
\text { right }\end{array}$ & $\begin{array}{l}\text { GTGGACCTGGCTGAGGAG } \\
\text { TCTTTCAATCGGGGATGTCT }\end{array}$ \\
\hline & probe & $\# 34$ & \\
\hline \multirow[t]{2}{*}{ growth arrest and DNAdamage-inducible protein alpha (GADD45A) } & primer & $\begin{array}{l}\text { left } \\
\text { right }\end{array}$ & $\begin{array}{l}\text { AGAGCAGAAGACCGAAAGGA } \\
\text { TGACTCAGGGCTTTGCTGA }\end{array}$ \\
\hline & probe & $\# 37$ & \\
\hline \multirow[t]{2}{*}{ lectin, galactoside-binding soluble 3 (LGALS3) } & primer & $\begin{array}{l}\text { left } \\
\text { right }\end{array}$ & $\begin{array}{l}\text { AAGCCCAATGCAAACAGAAT } \\
\text { TCATTGAAGCGTGGGTTAAA }\end{array}$ \\
\hline & probe & $\# 155$ & \\
\hline \multirow[t]{2}{*}{ wee1-like protein kinase (WEE1) } & primer & $\begin{array}{l}\text { left } \\
\text { right }\end{array}$ & $\begin{array}{l}\text { TCTGCGTGGGCAGAAGAT } \\
\text { TCTGTAGTTTTCACTTATAGCATCAGC }\end{array}$ \\
\hline & probe & $\# 31$ & \\
\hline \multirow[t]{2}{*}{ calponin } & primer & $\begin{array}{l}\text { left } \\
\text { right }\end{array}$ & $\begin{array}{l}\text { GCTGTCAGCCGAGGTTAAGA } \\
\text { CCCTCGATCCACTCTCTCAG }\end{array}$ \\
\hline & probe & $\# 32$ & \\
\hline \multirow[t]{2}{*}{ caldesmon } & primer & $\begin{array}{l}\text { left } \\
\text { right }\end{array}$ & $\begin{array}{l}\text { GAGCGTCGCAGAGAACTTAGA } \\
\text { TTCCTCTGGTAGGCGATTCTT }\end{array}$ \\
\hline & probe & $\# 32$ & \\
\hline
\end{tabular}

Table 1: A list of primer pairs and probes for each gene.

(a)

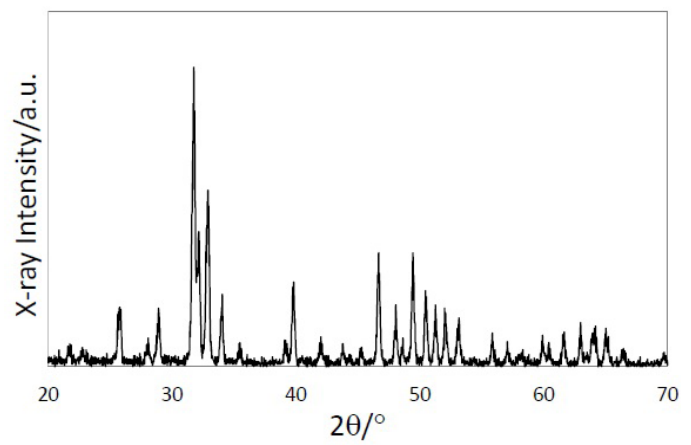

(c)

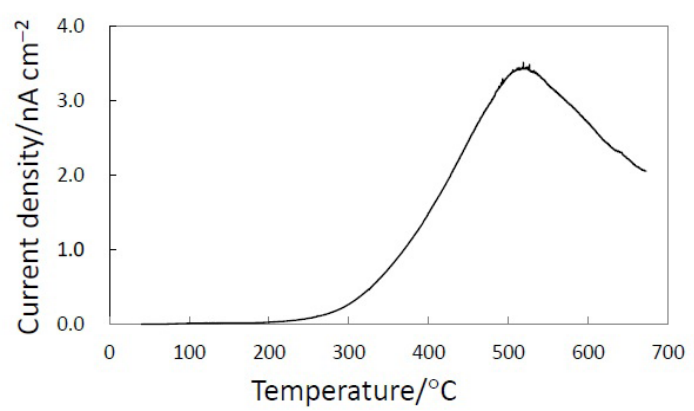

(b)

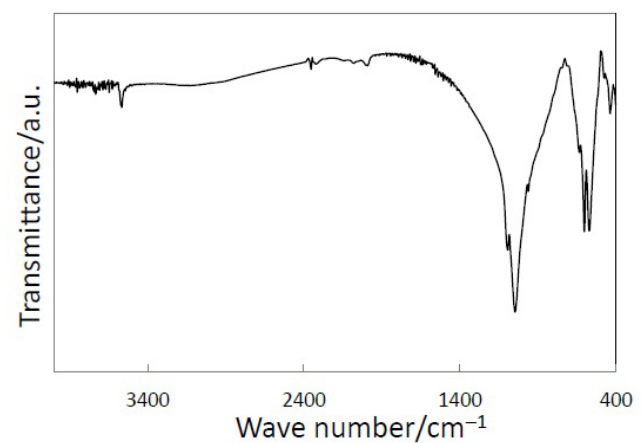

Figure 1: Characterization of the polarized hydroxyapatite (HAp). (a) X-ray diffraction pattern, (b) FTIR spectrum, and (c) thermally stimulated depolarization current spectrum of polarized HAp. 
Citation: Hattori T, Igarashi K, Miyazaki H, Aizawa M, Katayama K, et al. (2016) An Electrostatic Field on a Bioceramic Growth Surface Suppressed Leiomyosarcoma Cell Proliferation but Accelerated Differentiation. Int J Metall Mater Eng 2: 127. doi: https://doi.org/10.15344/2455-2372/2016/127

Page 5 of 6

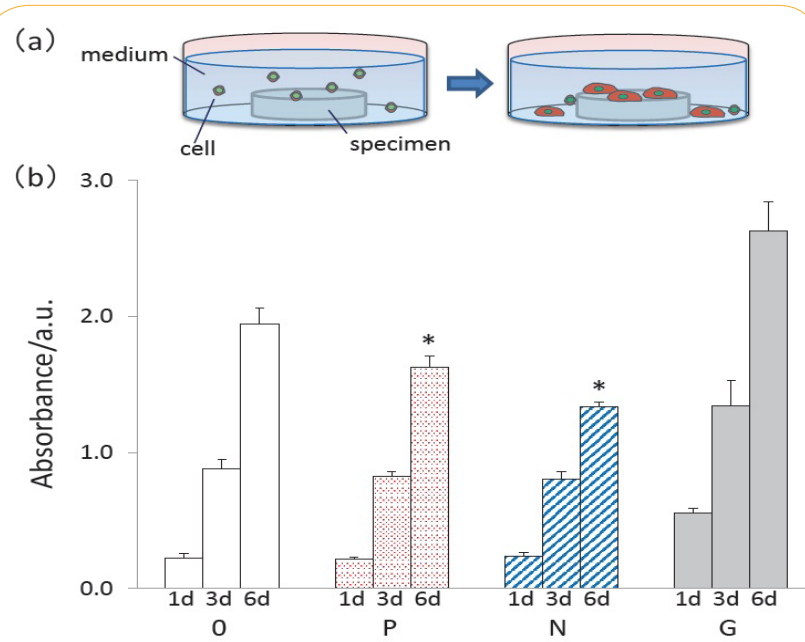

Figure 2: (a) Schematic diagram of SK cell culture on a specimen. (b) MTT assay at 1,3, and $6 \mathrm{~d}$ after seeding on $\mathrm{N}$ - surface (blue shaded area), $\mathrm{P}$ - surface (red spotted area), and 0-surface (white area) of hydroxyapatite and glass surface $(\mathrm{G}$, gray area). Results are the mean \pm standard deviation $(\mathrm{N}=4){ }^{*}: \mathrm{P}<0.05$, compared with 0 -surface.
$\mathrm{N}$-surface for $3 \mathrm{~d}$ before they were harvested for analysis showed a substantial gene expression change in 10 genes in comparison with 0 surface-cells (Figure 3 ). The genes showing increased expression were anaphase-promoting complex subunit 4 (ANAPC4), cyclindependent kinase 2 (CDK2), cyclin-dependent kinase inhibitor $2 \mathrm{~A}$ and $2 \mathrm{~B}(\mathrm{CDKN} 2 \mathrm{~A}, \mathrm{CDKN} 2 \mathrm{~B})$, growth arrest and DNA-damageinducible protein alpha (GADD45A), E2F transcription factor 3 (E2F3), retinoblastoma 1 (RB1), and Wee1-like protein kinase (WEE1). Decreased expression was observed for CDK4 and ataxiatelangiectasia mutated gene (ATM). The responding genes on the $\mathrm{N}$-surface could be classified as mitosis inhibitors (ANAPC4), CDK4 inhibitors (CDKN2A and CDKN2B), and DNA damage checkpoints (GADD45A, WEE1, RB1, and ATM), and are mainly considered to be in the tumor suppressors subset of the cell cycle-related genes [27-29]. Substantial expression changes were detected in four genes from samples grown on the Psurface (in comparison with 0-surface cells) (Figure 4). The only up-regulated gene was RB1 and the three down-regulated genes were ANAPC4, CDK4, and lectin, galactosidebinding soluble 3 (LGALS3). LGALS3 is up-regulated in many malignant tumors and is involved in modulating inflammation and apoptosis [30]. Genes with less than substantial changes in expression in P-surface cells were also categorized as tumor suppressors. There were no obvious changes in the apoptosisrelated genes, such as B-cell

(a)
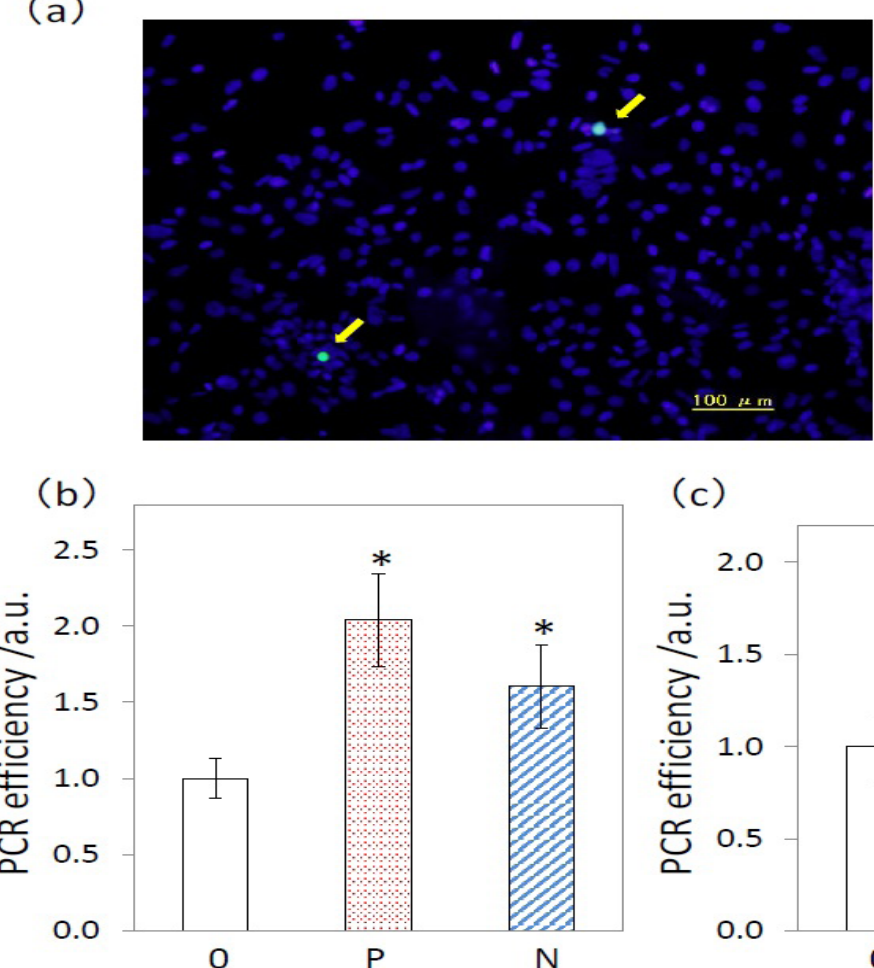

(c)

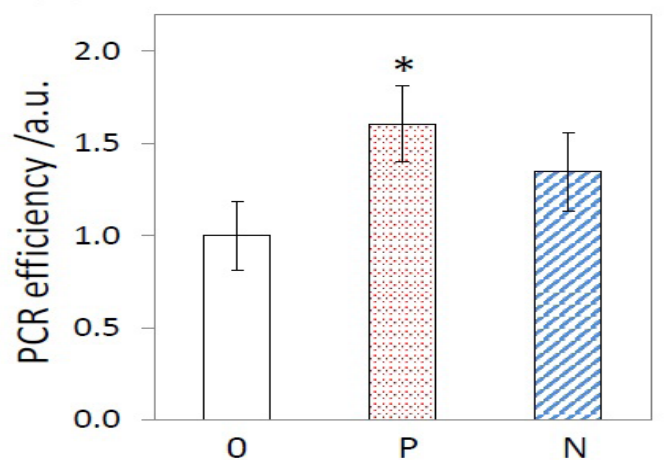

Figure 3; (a) A representative image of SK cells cultured on the polarized hydroxyapatite with TUNEL staining indicated by arrows. DAPI was used as a nuclear counterstain. Scale bar, $100 \mu \mathrm{m}$. Quantitative real-time RT-PCR analysis of (b) calponin and (c) caldesmon mRNA levels for evaluating the differentiation of SK cells on N- surface (blue shaded area), Psurface (red spotted area), and 0 -surface (white area) of hydroxyapatite. Results are the mean \pm standard deviation $(\mathrm{N}=4)$. *: $P<0.05$, compared with 0 -surface.

\section{Real-time PCR arrays for cell cycle-related genes}

To investigate the influence of polarization on the balance of proliferation and differentiation of SK cells, the expression of 84 cell cycle-related genes were analyzed using the RealTime ready Human Cell Cycle Regulation Panel. Cells that had been cultured on the lymphoma 2 (BCL2), BCL2-associated X protein (BAX), baculoviral inhibitor of apoptosis repeat-containing 5 (BIRC5), and tumor protein p53 (TP53) among the three specimens.

Next, the genes that displayed substantial differences in expression between N- and P- surfaces, ANAPC4, LGALS3, CDKN2A, CDK2, 
Citation: Hattori T, Igarashi K, Miyazaki H, Aizawa M, Katayama K, et al. (2016) An Electrostatic Field on a Bioceramic Growth Surface Suppressed Leiomyosarcoma Cell Proliferation but Accelerated Differentiation. Int J Metall Mater Eng 2: 127. doi: https://doi.org/10.15344/2455-2372/2016/127

Page 5 of 6

(a)

\begin{tabular}{|c|c|c|c|c|c|c|}
\hline ABL 1 & CCNB2 & CDC14A & CDK8 & $\mathrm{E} 2 \mathrm{~F} 1$ & MAD2L1 & RBL2 \\
\hline ANAPC2 & $\mathrm{CCNC}$ & CDC16 & CDKN1A & $\mathrm{E} 2 \mathrm{~F} 2$ & MAD2L2 & SKP2 \\
\hline ANAPCQ & CCND1 & $\mathrm{CDC} 2$ & CDKN1B & E2F3 & MCM2 & TFDP1 \\
\hline ATM & CCND2 & $\mathrm{CDC} 20$ & CDKN2A & $\mathrm{E} 2 \mathrm{~F} 4$ & МсM3 & TFDP2 \\
\hline ATR & CCND3 & CDC25A & CDKN2B & E2F5 & MYC & TP53 \\
\hline BAX & CCNE1 & CDC25B & CDKN3 & E2F6 & PCNA & WEE1 \\
\hline $\mathrm{BCCIP}$ & CCNE2 & CDC25C & CHEK1 & GADD45A & PLK1 & \\
\hline $\mathrm{BCL} 2$ & CCNF & $\mathrm{CDC} 34$ & CHEK 2 & GTF $2 \mathrm{H} 1$ & RAD1 & \\
\hline BIRC5 & CCNG1 & CDK2 & CKS1B & GTSE1 & RAD17 & \\
\hline BRCA1 & CCNG2 & CDQRA & CKS2 & JUN & RAD51 & \\
\hline BRCA2 & $\mathrm{CCNH}$ & CDK5R1 & CUL1 & KNTC1 & RAD9A & \\
\hline CCNA2 & CCNT1 & CDK6 & CUL2 & KPNA2 & RB1 & \\
\hline CCNB1 & CCNT2 & CDK7 & CUL3 & LGALS3 & RBL1 & \\
\hline
\end{tabular}

(b)

\begin{tabular}{|c|c|c|c|c|c|c|}
\hline ABL1 & CCNB2 & CDC14A & CDK8 & E2F1 & MAD2L1 & RBL2 \\
\hline ANAPC2 & CCNC & CDC16 & CDKN1A & E2F2 & MAD2L2 & SKP2 \\
\hline ANAPC4 & CCND1 & CDC2 & CDKN1B & E2F3 & MCM2 & TFDP1 \\
\hline ATIM & CCND2 & CDC20 & CDKN2A & E2F4 & MCM3 & TFDP2 \\
\hline ATR & CCND3 & CDC25A & CDKN2B & E2F5 & MYC & TP53 \\
\hline BAX & CCNE1 & CDC25B & CDKN3 & E2F6 & PCNA & WEE1 \\
\hline BCCIP & CCNE2 & CDC25C & CHEK1 & GADD45A & PLK1 & \\
\hline BCL2 & CCNF & CDC34 & CHEK2 & GTF2H1 & RAD1 & \\
\hline BIRC5 & CCNG1 & CDK2 & CKS1B & GTSE1 & RAD17 & \\
\hline BRCA1 & CCNG2 & CDRß4 & CKS2 & JUN & RAD51 & \\
\hline BRCA2 & CCNH & CDK5R1 & CUL1 & KNTC1 & RAD9A & \\
\hline CCNA2 & CCNT1 & CDK6 & CUL2 & KPNA2 & RB1 & \\
\hline CCNB1 & CCNT2 & CDK7 & CUL3 & LGALS3 & RBL1 & \\
\hline
\end{tabular}

Figure 4: RT-PCR array for cell cycle-related genes on (a) N-surface and (b) P-surface compared to 0-surface after normalization with GAPDH. The names of genes that showed increases greater than 1.75-fold are indicated with bold font. Genes with decreases to less than 0.75 -fold are indicated with white bold.

(a)

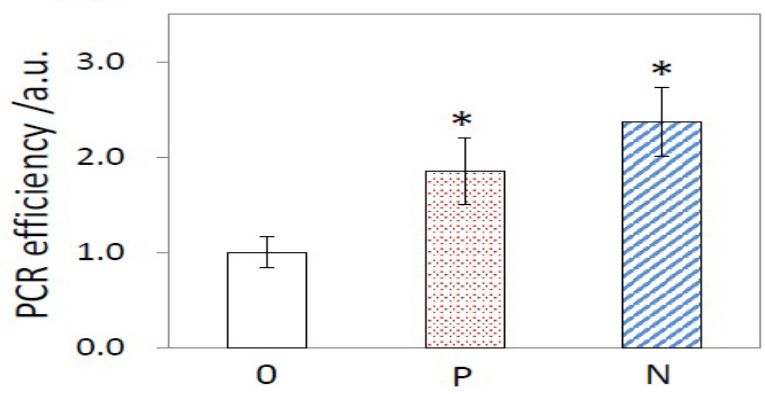

(c)

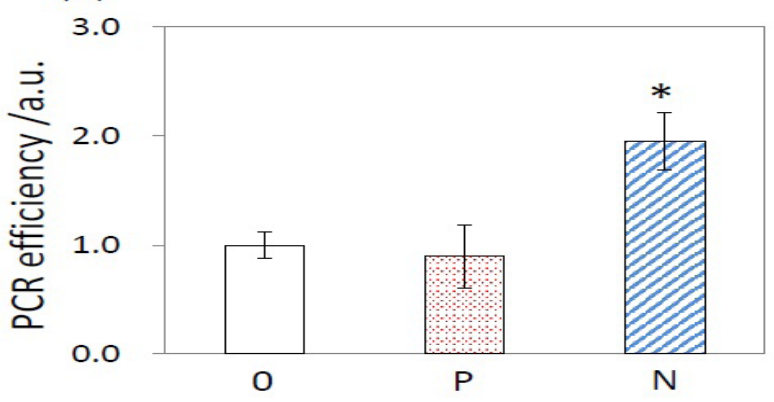

(b)

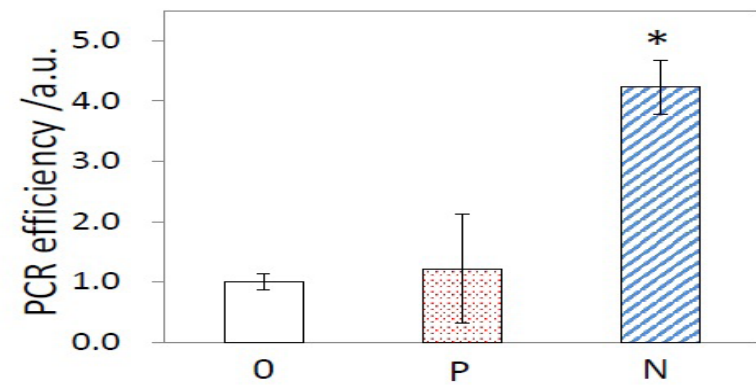

Figure 5: Quantitative real-time RT-PCR measurements of (a) Wee1, (b) GADD45A, and (c) CDKN2A mRNA levels in SK cells that were grown on N- surface (blue shaded area), P-surface (red spotted area), and 0-surface (white area) of hydroxyapatite. Results are the mean \pm standard deviation $(\mathrm{N}=4)$.

*: P $<0.05$, compared with 0 -surface. GAPDH was used as a control. 
Citation: Hattori T, Igarashi K, Miyazaki H, Aizawa M, Katayama K, et al. (2016) An Electrostatic Field on a Bioceramic Growth Surface Suppressed Leiomyosarcoma Cell Proliferation but Accelerated Differentiation. Int J Metall Mater Eng 2: 127. doi: https://doi.org/10.15344/2455-2372/2016/127

Page 5 of 6

GADD45A, and WEE1 were quantified using qRT-PCR. It was found that the expressions of CDKN2A, GADD45A, and WEE1 increased significantly in the Nsurface-cells compared to their expression in the P-surface cells, and the expression differences in the other genes were not significant (Figure 5).

\section{Discussion}

We applied electric energies as external stimuli to alter the leiomyosarcoma cells onto the path to myogenic differentiation and examined the effects on proliferation rates, markers of differentiation, and the expression of genes related to the cell cycle.

SK cells continued to proliferate on the polarized apatite as well as on the control surfaces, nonpolarized apatite and culture glass. The cell proliferation rates on the polarized apatite were lower, and the expressions of calponin and caldesmon, differentiation markers of the smooth muscle cell, were higher than in the control samples. The decrease in proliferation rates correlated with the promotion of differentiation between cells grown with and without polarization but not between cells grown on Nand P-surfaces. Only a very low level of apoptosis was observed in any of the specimens, according to TUNEL staining and qRT-PCR cell cycle-related gene array results. Therefore, the decrease in the proliferation rates must have resulted from DNA replication inhibition. This change in the cell from a malignant to a more normal state is similar to what has been reported to occur in stem cells where cell cycle withdrawal can couple with induction of differentiation $[31,32]$.

The results of the qRT-PCR panel of the cell cycle-related genes included up-regulation of RB1 and down-regulation of CDK4 in cells from both $\mathrm{N}$ - and P-surfaces compared to cells from the 0 -surface. The RB1 gene product is a key molecule in cell cycle regulation and functions as a tumor suppressor that negatively regulates progression from G0 to G1 and into S phase [33]. In addition, its expression is upregulated in many tissue types, including muscle while undergoing terminal differentiation, and it interacts with tissuespecific transcription factors [34-36]. CDK4 is known to be involved in regulation of the cell cycle at G1 phase. Taken together, the data suggest that SK cells on the polarized specimens were inhibited at the G1/S transition and switched toward myogenic differentiation.

Moreover, CDKN2A, WEE1, and GADD45A were up-regulated, especially on the N-surface. CDKN2A and WEE1 are checkpoint kinases at G1 and G2 phase, respectively [26,29]. GADD45A is stress inducible and is involved in the maintenance of genomic stability, DNA repair, and suppression of cell growth at G2 phase, as well as promoting the activation of epigenetic genes by repair-mediated DNA demethylation $[37,38]$. On the basis of those cell stress responses, the $\mathrm{N}$-surface had stronger effects on the cell cycle than the P-surface, which contributed to the suppression of cell proliferation on the $\mathrm{N}$-surface

Several studies have reported the possibility of using electric energies for the diagnosis and treatment of malignant tumors [39,57]. Mechanisms, such as the relationship between growth factor signal and electric fields, have been widely analyzed [40,41]. An advantage of our method is that it uses stored charges in the implant and therefore does not require an external apparatus at the point of use, unlike the electro-stimulation models. The stored charges in the polarized apatite should be quite enduring, with a relaxation time at physiological temperature calculated to be more than 100 years based upon TSDC measurements [26]. Further study is needed to identify and optimize the most appropriate materials for implantation into the body.

In summary, surface fields around polarized bioceramics can alter the balance of proliferation and differentiation of leimyosarcoma cells via influences on cell cycle regulation. Greater understanding of cellular responses to electric energies could be helpful for the development of differentiationinducing therapeutic strategies for leimyosarcoma and other cancers.

\section{Competing Interests}

The authors declare that they have no competing interests.

\section{Funding}

This work was supported by Grants-in-Aid for Scientific Research (C)(15K01278) from JSPS.

\section{References}

1. Pereda AE (2014) Electrical synapses and their functional interactions with chemical synapses. Nat Rev Neurosci 15: 250-263.

2. Mycielska ME, Djamgoz MB (2004) Cellular mechanisms of direct-current electric field effects: galvanotaxis and metastatic disease. J Cell Sci 117: 1631-1639.

3. Sato MJ, Kuwayama $\mathrm{H}$, van Egmond WN, Takayama ALK, Takagi $\mathrm{H}$, et al. (2009) Switching direction in electric-signal-induced cell migration by cyclic guanosinemonophosphate and phosphatidylinositol signaling. Proc Natl Acad Sci USA 106: 6667-6672.

4. Yang W, Wu YH, Yin D, Koeffler HP, Sawcer DE, Vernier PT, Gundersen MA (2011) Differential sensitivities of malignant and normal skin cells to nanosecond pulsed electric fields. Tech Cancer Res Treat 10: 281-286.

5. Kirson ED, Dbalý V, Tovarys F, Vymazal J, Soustiel JF, et al. (2007) Alternating electric fields arrest cell proliferation in animal tumor models and human brain tumors. Proc Natl Acad Sci USA 104: 10152-10157.

6. Kirson ED, Giladi M, Gurvich Z, Itzhaki A, Mordechovich D, et al. (2009) Alternating electric fields (TTFields) inhibit metastatic spread of solid tumors to the lungs. Clin Exp Metastasis 26: 633-640

7. Miklavcic D, Corovic S, Pucihar G, Pavselj N (2006) Importance of tumour coverage by sufficiently high local electric field for effective electrochemotherapy. EJC suppl 4: 45-51.

8. Yamashita K, Oikawa N, Umegaki T (1996) Acceleration and deceleration of bonelike crystal growth on ceramic hydroxyapatite by electric poling. Chem Mater 8: 2697-2700.

9. Ma C, Nagai A, Yamazaki Y, Toyama T, Tsutsumi Y, et al. (2012) Electrically polarized micro-arc oxidized $\mathrm{TiO}_{2}$ coatings with enhanced surface hydrophilicity. Acta Biomater 8: 860-865.

10. Terafder S, Banerjee S, Bandyopadhyay A, Bose S (2010) Electrically polarized biphasic calcium phosphates: adsorption and release of bovine serum albumin. Langmuir Lett 26: 16625-16629.

11. Nagai A, Yamasaki Y, Ma C, Nozaki K, Toyama T, Yamashita K (2012) Response of osteoblastlike MG63 cells to TiO2 layer prepared by micro-arc oxidation and electric polarization. J Eur Ceram Soc 32: 2647-2652.

12. Itoh S, Nakamura S, Nakamura M, Shinomiya K, Yamashita K (2006) Enhanced bone ingrowth into hydroxyapatite with interconnected pores by Electrical Polarization. Biomaterials 27: 5572-5579.

13. Nozaki K, Wang W, Horiuchi N, Nakamura M, Takakuda K et al. (2014) Enhanced osteoconductivity of titanium implant by polarization-induced surface charges. J Biomed Mater Res 102 A: 3077-3086.

14. Nagai A, Yamashita K, Imamura M, and Azuma H (2008) Hydroxyapatite electret accelerates reendothelialization and attenuates intimal hyperplasia occurring after endothelial removal of the rabbit carotid artery. Life Sci 82: 1162-1168.

15. Wildwater M1, The I, van den Heuvel S (2007) Coordination of cell proliferation and differentiation: finding a GEM in the root? Dev Cell 12 841-842. 
Citation: Hattori T, Igarashi K, Miyazaki H, Aizawa M, Katayama K, et al. (2016) An Electrostatic Field on a Bioceramic Growth Surface Suppressed Leiomyosarcoma Cell Proliferation but Accelerated Differentiation. Int J Metall Mater Eng 2: 127. doi: https://doi.org/10.15344/2455-2372/2016/127

Page 5 of 6

16. Huang ME, Ye YI, Chen SR, Chai JR, Lu JX, Zhoa L, Gu LJ, Wang ZY (1988) Use of all-transretinoic acid in the treatment of acute promyelocytic leukemia. Blood 72: 567-572.

17. Schenk T, Stengel S, Zelent A (2014) Unlocking the potential of retinoic acid in anticancer therapy. Br J Cancer 111: 2039-2045

18. Kawamata H, Tachibana M, Fujimori T, Imai $\mathrm{Y}$ (2006) Differentiationinducing therapy for solid tumors. Curr Pharm Des 12: 379-385.

19. Colombo C, Miceli R, Collini P, Radaelli S, Palassini E, et al. (2012) Leiomyosarcoma and sarcoma with myogenic differentiation: two different entities or 2 faces of the same disease? Cancer 118: 5349-5357.

20. Neganova I, Lako M (2008) G1 to S phase cell cycle transition in somatic and embryonic stem cells. J Anat 213: 30-44.

21. Calder A, Roth-Albin I, Bhatia S, Polquil C, Lee JH, et al. (2013) Lengthened $\mathrm{G} 1$ phase indicates differentiation status in human embryonic stem cells. Stem Cell Dev 22: 279-295

22. Hisaoka M, Wei-Qi S, Jian W, Morio T, Hashimoto H (2001) Specific but variable expression of $\mathrm{h}$-caldesmon in leiomyosarcomas: an immunohistochemical reassessment of a novel myogenic marker. Appl Immunohistochem Mol Morphol 9: 302-308.

23. Kimura Y, Morita T, Hayashi K, Miki T, Sobue K (2010) Myocardin functions as an effective inducer of growth arrest and differentiation in human uterine leiomyosarcoma cells. Cancer Res 70: 501-511.

24. Yamashita K, Kitagaki K, Umegaki T (1995) Thermal-instability and proton conductivity of ceramic hydroxyapatite at high-temperatures. J Am Ceram Soc 78: 1191-1197.

25. Horiuchi N, Nakamura M, Nagai A, Katayama K, Yamashita K (2012) Proton conduction related electrical dipole and space charge polarization in hydroxyapatite. J Apps Phys 112: 074901.

26. Nagai A, Tanaka K, Tanaka Y, Nakamura M, Hashimoto K, et al. (2011) Electric polarization and mechanism of B-type carbonated apatite ceramics. J Biomed Mater Res A 99: 116-124.

27. Nakayama KI, Nakayama K (2006) Ubiquitin ligases: cell-cycle control and cancer. Nat Rev Cancer 6: 369-381.

28. Jin S, Tong T, Fan W, Fan F, Antinore MJ, et al. (2002) GADD45-induced cell cycle G2-M arrest associates with altered subcellular distribution of cyclin B1 and is independent of p38 kinase activity. Oncogene 21: 86968704.

29. Okamoto K, Sagata N (2007) Mechanism for inactivation of the mitotic inhibitory kinase Wee1 at M phase. Proc Natl Acad Sci U S A 104: 37533758.

30. Giordano M, Croci DO, Rabinovich GA (2013) Galectins in hematological malignancies. Curr Opin Hematol 20: 327-335.

31. Ben-Porath I, Thomson MW, Carey VJ, Ge R, Bell GW, et al. (2008) An embryonic stem cell-like gene expression signature in poorly differentiated aggressive human tumors. Nat Genet 40: 499-507.

32. Friedmann-Morvinski D, Verma IM (2014) Dedifferentiation and reprogramming: origins of cancer stem cells. EMBO Rep 15: 244-253.

33. Friend SH, Bernards R, Rogelj S, Weinberg RA, Rapaport JM, et al. (1986) A human DNA segment with properties of the gene that predisposes to retinoblastoma and osteosarcoma. Nature 323: 643-646.

34. Indovina P, Marcelli E, Casini N, Rizzo V, Giordano A (2013) Emerging roles of RB family: new defense mechanisms against tumor progression. J Cell Physiol 228: 525-535.

35. Goodrich DW (2006) The retinoblastoma tumor-suppressor gene, the exception that proves the rule. Oncogene 25: 5233-5243.

36. De Falco G, Comes F, Simone C (2006) pRb: master of differentiation Coupling irreversible cell cycle withdrawal with induction of muscle-specific transcription. Oncogene 25: 5244-5249.

37. Hollander MC, Fornace AJ Jr (2002) Genomic instability, centrosome amplification, cell cycle checkpoints and Gadd45a. Oncogene 21: 6228 6233.

38. Barreto G, Schäfer A, Marhold J, Stach D, Swaminathan SK, et al. (2007) Gadd45a promotes epigenetic gene activation by repair-mediated DNA demethylation. Nature 445: 671-675.
39. Cuzick J, Holland R, Barth V, Davies R, Faupel M, et al. (1998) Electropotential measurements as a new diagnostic modality for breast cancer. Lancet 352: 359-363.

40. Rodrigues M, Griffith LG, Wells A (2010) Growth factor regulation of proliferation and survival of multipotential stromal cells. Stem Cell Res Ther 1: 32.

41. Pu J, McCaig CD, Cao L, Zhao Z, Segall JE, et al. (2007) EGF receptor signalling is essential for electric-field-directed migration of breast cancer cells. J Cell Sci 120: 3395-3403.
This article was originally published in a special issue:

Bioceramics: Designing, Applications and Challenges

Handled by Editor(s):

\section{Dr. Kimihiro Yamashita}

Department of Inorganic Materials, Institute of Biomaterials

and Bioengineering

Tokyo Medical and Dental University

Japan 